\title{
Geographic Influence on Genetic Structure in the Widespread Neotropical Tree Simarouba amara (Simaroubaceae)
}

\section{Landscape genetic diversity of Simarouba amara}

\author{
Britta Denise Hardesty - Christopher W. Dick • \\ James L. Hamrick • Bernd Degen • Stephen P. Hubbell • \\ Eldredge Bermingham
}

Received: 16 September 2009 / Accepted: 4 February 2010 / Published online: 27 March 2010

(C) Springer Science+Business Media, LLC 2010

\begin{abstract}
This study aimed to assess the population genetic structure of a widespread Neotropical tree species, Simarouba amara, at local, regional and continental spatial scales. We used five microsatellite loci to examine genetic variation in 14 natural populations ( $N=478$ individuals) of this vertebrate-
\end{abstract}

Communicated by: Ramesh K. Aggarwal

Britta D. Hardesty and Christopher W. Dick contributed equally to analysis and writing

B. D. Hardesty · C. W. Dick · S. P. Hubbell · E. Bermingham Smithsonian Tropical Research Institute,

PO Box 0843-03092, Balboa, Ancón, Republic of Panama

B. D. Hardesty $\cdot$ J. L. Hamrick $\cdot$ S. P. Hubbell

Plant Biology Department, University of Georgia,

Athens, GA 30602, USA

C. W. Dick

Department of Ecology and Evolutionary Biology and Herbarium, University of Michigan,

Ann Arbor, MI 48109, USA

\section{B. Degen}

Johann Heinrich von Thuenen-Institut, Institute of Forest Genetics,

22927 Grosshansdorf, Germany

\section{S. P. Hubbell}

Department of Ecology and Evolutionary Biology,

University of California Los Angeles,

Los Angeles, CA 90095, USA

Present Address:

B. D. Hardesty $(\bowtie)$

CSIRO Sustainable Ecosystems,

PO Box 780, Atherton, QLD 4883, Australia

e-mail: denise.hardesty@csiro.au dispersed rain forest tree species in Panama, Ecuador, and French Guiana. Estimates of genetic differentiation $\left(F_{\text {st }}\right.$ and $\left.R_{\mathrm{st}}\right)$ were significant among all but one population pair and global differentiation was moderate $\left(F_{\mathrm{st}}=0.25, R_{\mathrm{st}}=0.33\right)$ with $94 \%$ of genetic variation ascribed to differences among three main geographic regions (Central America, Western Ecuador, Amazon basin). There was no evidence of isolation by distance within regions. Allele-size mutations contributed significantly $\left(R_{\mathrm{ST}}>F_{\mathrm{ST}}\right)$ to the divergences between cisand trans-Andean populations, highlighting the role of the northern Andean cordilleras as an important geographic barrier for this species.

Keywords Biogeography · Genetic diversity - Isolation by distance $\cdot$ Microsatellite DNA - Neotropics .

Population structure $\cdot$ Tropical tree
Abbreviations
BCI Barro Colorado Island
IBD Isolation by distance
PCR Polymerase chain reaction
SSR Simple sequence repeats

\section{Introduction}

Vertebrate dispersed tropical tree species typically occur in low population densities (Hubbell and Foster 1983) and many species are threatened with the loss of genetic diversity due to anthropogenic extinction of local populations, reduced population sizes, and the reduction or extirpation of their animal dispersal agents (Hamrick 2004). Potential consequences of the loss of genetic 
diversity through fragmentation and deforestation have heightened interest in determining how genetic diversity is distributed within and among populations of tropical trees. In the past two decades, population genetic structure has been characterized in dozens of tropical tree species (reviewed in Dick et al. 2008) and most studies have focused on genetic variability of populations within regions. These studies have found significantly higher levels of among population variation (e.g. $F_{\mathrm{st}}$ ) in tropical trees than in their temperate zone counterparts (Dick et al. 2008; Hamrick and Loveless 1989; Hamrick and Murawski 1991). However, relatively few studies have sampled broadly at regional or intercontinental spatial scales (Aide and Rivera 1999; Dick and Heuertz 2008) even though such sampling might provide insights into the role of biogeographic forces in shaping patterns of genetic variation.

Variability in mating systems, life form, dispersal mode, and other life history characteristics shape patterns of genetic diversity within and among plant populations (Hamrick and Godt 1989, 1996). Because tropical tree species exhibit such a wide array of life history traits, generalizations are difficult to make, though with knowledge of pollen and seed dispersal mechanisms, reasonable predictions for the distribution of genetic diversity can be made (see Hamrick 1994a). The majority of tropical trees appear to be outcrossing and exhibit high levels of gene flow and genetic diversity at local and regional spatial scales (Loveless 1992; Alvarez-Buylla et al. 1996; Nason and Hamrick 1997). However, in recent South and Central American studies of mahogany (Lemes et al. 2003; Novick et al. 2003; Lemes et al. 2010), Spanish-cedar (Cavers et al. 2003), and a study of Symphonia globulifera in both Afroand Neotropical forests (Dick et al. 2003; Dick and Heuertz 2008), high regional differentiation has been detected. These studies have suggested that geographic barriers play a key role in structuring intraspecific variation in widespread tropical forest tree species.

Our goal was to examine genetic diversity and differentiation of a widespread Neotropical tree species, Simarouba amara, across multiple sites at regional (within Panama, within French Guiana and within Ecuador) and continental (Central and South American) scales. We used microsatellite DNA markers to address the following questions: What is the level of genetic diversity within populations and how does this vary among populations of this widespread tree species? Do patterns of genetic differentiation correspond to broadly defined biogeographic regions? Are patterns of isolation by distance (Wright 1943) observed at regional or continental spatial scales? Is phylogeographic structure, measured as the contribution of mutations to genetic differentiation (Hardy et al. 2003), evident over the range of $S$. amara?

\section{Study Species}

Simarouba amara Aubl. (Simaroubaceae) is a dioecious, vertebrate-dispersed diploid tree species with a geographic range that extends for more than $3,300 \mathrm{~km}$ (shortest distance estimate) from Costa Rica to coastal Ecuador, and from the Bolivian Amazon to French Guiana. Trees grow to ca. $35 \mathrm{~m}$ with a maximum reported diameter at breast height (dbh) of $70 \mathrm{~cm}$ on Barro Colorado Island (BCI), Panama (Croat 1978). Simarouba amara occurs at low population densities typical of tree species in mature lowland moist tropical forest. Within the two 50-ha Forest Dynamics Plots (FDP) in Panama (BCI) and Ecuador (Yasuni), S. amara occurs at a density of 5.32 and 0.68 trees of $>10 \mathrm{~cm}$ dbh per hectare, respectively (Losos and Leigh 2004). At the easternmost site in French Guiana, the density of $>10 \mathrm{~cm}$ dbh $S$. amara trees is 0.37 individuals per hectare.

Simarouba amara is a fast-growing intermediate-to-high light requiring species (Clark and Clark 2001) and on BCI flowers from February-May. The unisexual flowers occur in terminal panicles composed of numerous, small $(<1 \mathrm{~cm}$ long), pale yellowish flowers. The floral syndrome of $S$. amara is typical of pollination by generalist small insects such as small bees and moths (Bawa 1990), which have been observed to visit its flowers on BCI. Ripe, fleshy purple-black drupes are produced within 1-3 months after pollination and are dispersed by numerous vertebrates including primates and frugivorous birds. Simarouba amara has been described as a 'locally used' tree for making paper, furniture building, interior construction, plywood, and matches in Central America (Rodriguez von Platen 2000). The species exhibits weak genetic structure at the scale of 50 ha at various size classes suggesting large neighborhood size (Hardesty et al. 2005). Microsatellitebased parentage analyses have shown that pollen and seed regularly move hundreds of meters to kilometers in the $\mathrm{BCI}$ forest (Hardesty et al. 2006; Hardesty 2007).

\section{Results}

The number of alleles per locus in the 14 populations sampled in the study (Table 1, Fig. 1) ranged from 8 to 29 (Table 2) with a mean of 13.6 alleles per locus (Table 3). The effective number of alleles per locus ranged from 2.1 at locus SA06 to 12.8 at locus SA27 (Table 3). Withinpopulation allelic diversity ranged from 2.8 to 9.0 alleles per locus per population (MON and YAS respectively; mean $=5.8$ ). Alleles generally differed by a factor of three nucleotides, which is consistent with a stepwise mutation model. No locus pairs demonstrated significant linkage disequilibrium. Mean expected heterozygosity $\left(H_{\mathrm{e}}\right)$ was higher than observed heterozygosity $\left(H_{\mathrm{o}}\right)$ at all loci 
Table 1 Country, name and (code) for each sample population, number of population on map M), number of individuals sampled per population $(\mathrm{N})$, location of each site (Latitude/Longitude) and elevation (Elev)

\begin{tabular}{|c|c|c|c|c|c|}
\hline Country & Population & $\mathrm{N}$ & Latitude & Longitude & Elev (m) \\
\hline Panama (PN) & Ft. Sherman (FTS) & 20 & $921^{\prime} 00^{\prime \prime} \mathrm{N}$ & $7957^{\prime} 00^{\prime \prime} \mathrm{W}$ & $106 \mathrm{~m}$ \\
\hline Panama & Santa Rita (SR) & 28 & $915^{\prime} 00^{\prime \prime} \mathrm{N}$ & $7937^{\prime} 00^{\prime \prime} \mathrm{W}$ & $528 \mathrm{~m}$ \\
\hline Panama & Cerro Jefe (CJ) & 32 & $915^{\prime} 00^{\prime \prime} \mathrm{N}$ & $7923^{\prime} 00^{\prime \prime} \mathrm{W}$ & $634 \mathrm{~m}$ \\
\hline Panama & Barro Colorado Is (BCI) & 50 & $910^{\prime} 00^{\prime \prime} \mathrm{N}$ & $7950^{\prime} 00^{\prime \prime} \mathrm{W}$ & $25 \mathrm{~m}$ \\
\hline Panama & Cerro Campana (CC) & 30 & $840^{\prime} 00^{\prime \prime} \mathrm{N}$ & $7955^{\prime} 00^{\prime \prime} \mathrm{W}$ & $463 \mathrm{~m}$ \\
\hline Panama & El Cope (EC) & 29 & $839^{\prime} 31^{\prime \prime} \mathrm{N}$ & $8035^{\prime} 25^{\prime \prime} \mathrm{W}$ & $678 \mathrm{~m}$ \\
\hline Panama & Alto de piedra Santa Fe Veraguas (ALP) & 30 & $831^{\prime} 19^{\prime \prime} \mathrm{N}$ & $8217^{\prime} 00^{\prime \prime} \mathrm{W}$ & $768 \mathrm{~m}$ \\
\hline Panama & Bocas del Toro (BdT) & 30 & $918^{\prime} 45^{\prime \prime} \mathrm{N}$ & $8217^{\prime} 00^{\prime \prime} \mathrm{W}$ & $171 \mathrm{~m}$ \\
\hline Panama & Cordillera del Montuoso (MON) & 30 & $743^{\prime} 57^{\prime \prime} \mathrm{N}$ & $8048^{\prime} 02^{\prime \prime} \mathrm{W}$ & $640 \mathrm{~m}$ \\
\hline Ecuador (EC) & Esmeraldas (ESME) & 35 & $036^{\prime} 00^{\prime \prime} \mathrm{S}$ & $8001^{\prime} 00^{\prime \prime} \mathrm{W}$ & $92 \mathrm{~m}$ \\
\hline Ecuador & Monkey Plot (MP) & 50 & $041^{\prime} 36^{\prime \prime} \mathrm{S}$ & $7628^{\prime} 15^{\prime \prime} \mathrm{W}$ & $229 \mathrm{~m}$ \\
\hline Ecuador & Tiputini (TIP) & 18 & $038^{\prime} 15^{\prime \prime} \mathrm{S}$ & $7609^{\prime} 39^{\prime \prime} \mathrm{W}$ & $203 \mathrm{~m}$ \\
\hline Ecuador & Yasuni (YAS) & 50 & $055^{\prime} 00^{\prime \prime} \mathrm{S}$ & $7524^{\prime} 00^{\prime \prime} \mathrm{W}$ & $214 \mathrm{~m}$ \\
\hline \multirow[t]{2}{*}{ French Guiana (FG) } & French Guiana (FG) & 47 & $518^{\prime} 00^{\prime \prime} \mathrm{N}$ & $5253^{\prime} 00^{\prime \prime} \mathrm{W}$ & $35 \mathrm{~m}$ \\
\hline & ALL SITES & 478 & & & \\
\hline
\end{tabular}

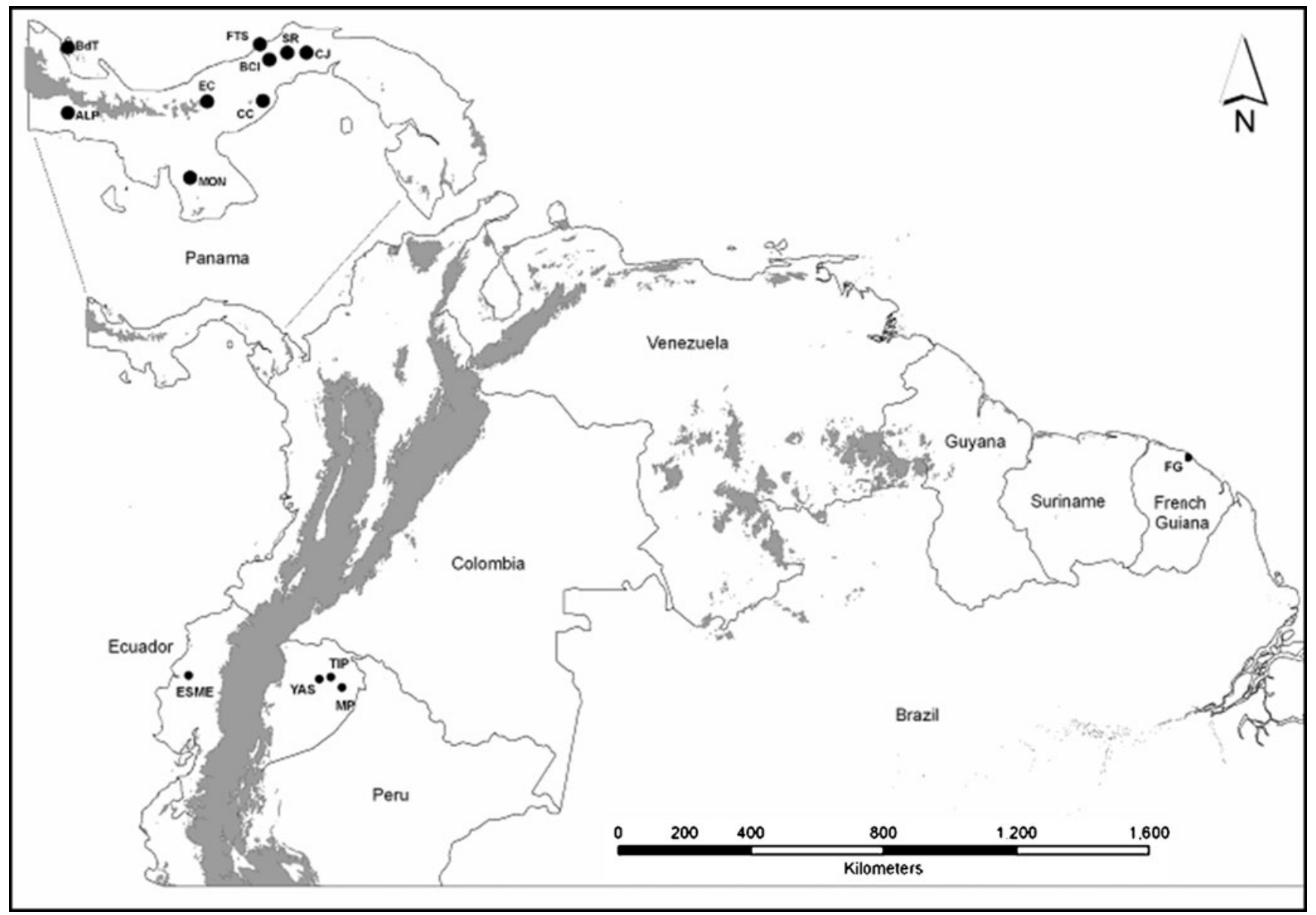

Fig. 1 Locations of the 14 Simarouba amara populations sampled across Panama, Ecuador, and French Guiana 
Table 2 Summary of microsatellite genetic diversity for each population (Pop), mean number of alleles per locus (A, (range)), number of effective alleles per locus $\left(\mathrm{A}_{\mathrm{e}}\right)$, ratio of effective alleles:alleles $\left(\mathrm{A}_{\mathrm{e}} / \mathrm{A}\right)$, number of private alleles $(\mathrm{Pa})$, heterozygosity observed $\left(\mathrm{H}_{\mathrm{o}}\right)$, and expected heterozygosity $\left(\mathrm{H}_{\mathrm{e}}\right)$ for each population. Mean and pooled values are given for each region and over all the regions. The inbreeding coefficient $\left(\mathrm{F}_{\text {is }}\right)$ is also presented for each population and for the Panama and Amazonia Regions (R)

\begin{tabular}{|c|c|c|c|c|c|c|c|c|}
\hline Region & Pop & A & $A_{e}$ & $\mathrm{~A}_{\mathrm{e}} / \mathrm{A}$ & $\mathrm{P}_{\mathrm{a}}$ & $\mathrm{H}_{\mathrm{o}}$ & $\mathrm{H}_{\mathrm{e}}$ & $\mathrm{F}_{\text {is }}$ \\
\hline \multirow[t]{11}{*}{ Panama } & FTS & $6.2(4-12)$ & 3.33 & 0.538 & 0 & 0.656 & 0.700 & 0.065 \\
\hline & SR & $6.3(4-12)$ & 3.29 & 0.522 & 2 & 0.562 & 0.696 & 0.195 \\
\hline & $\mathrm{CJ}$ & $6.6(3-12)$ & 3.16 & 0.479 & 1 & 0.576 & 0.684 & 0.171 \\
\hline & $\mathrm{BCI}$ & $7.0(6-10)$ & 2.38 & 0.340 & 4 & 0.496 & 0.538 & 0.079 \\
\hline & $\mathrm{CC}$ & $4.0(2-6)$ & 2.06 & 0.514 & 0 & 0.509 & 0.514 & 0.173 \\
\hline & $\mathrm{EC}$ & $5.0(2-12)$ & 2.22 & 0.443 & 0 & 0.468 & 0.549 & 0.134 \\
\hline & ALP & $4.6(2-8)$ & 2.10 & 0.457 & 0 & 0.438 & 0.524 & 0.166 \\
\hline & $\mathrm{BdT}$ & $5.4(2-8)$ & 2.39 & 0.442 & 2 & 0.578 & 0.581 & 0.007 \\
\hline & MON & $2.8(1-4)$ & 1.58 & 0.659 & 0 & 0.351 & 0.368 & 0.064 \\
\hline & Mean & 5.32 & 2.50 & 0.488 & 1.0 & 0.515 & 0.573 & \\
\hline & Pooled & $53(7-19)$ & 3.97 & 0.335 & 9 & - & 0.661 & 0.191 (R) \\
\hline Coastal Ecuador & ESME & $5.6(2-7)$ & 2.47 & 0.441 & 0 & 0.594 & 0.595 & 0.001 \\
\hline \multirow[t]{5}{*}{ Amazonia } & MP & $8.0(3-16)$ & 2.79 & 0.348 & 1 & 0.529 & 0.641 & 0.176 \\
\hline & TIP & $4.4(2-5)$ & 2.21 & 0.502 & 1 & 0.524 & 0.547 & 0.043 \\
\hline & YAS & $9.0(3-17)$ & 3.77 & 0.410 & 4 & 0.494 & 0.560 & 0.120 \\
\hline & Mean & 6.8 & 2.81 & 0.425 & 1.5 & 0.535 & 0.586 & \\
\hline & Pooled & $54(4-22)$ & 4.68 & 0.402 & 6 & - & 0.677 & $0.312(\mathrm{R})$ \\
\hline French Guiana & PFG & $6.6(2-15)$ & 2.14 & 0.324 & 1 & 0.529 & 0.532 & 0.005 \\
\hline Overall Mean & & 13.6 & 2.48 & 0.413 & 1.14 & 0.526 & 0.555 & \\
\hline Overall Pooled & & $68(8-29)$ & 5.53 & 0.354 & 16 & - & 0.730 & \\
\hline
\end{tabular}

(Table 3) and within all populations (Table 2). Homozygote excess was particularly pronounced at SA06, which had a high likelihood of containing null alleles.

Mean expected heterozygosity was 0.730 , and ranged from 0.368 at $\mathrm{MON}$ to 0.700 at FTS (mean $=0.555$ ) (Table 2). When tested for significant departure from Hardy Weinberg equilibrium, $10 \%$ of 70 tests demonstrated a significant departure at the 5\% confidence level (though valid $\mathrm{H}-\mathrm{W}$ tests were not possible in 42 cases). Of the fourteen populations, only $\mathrm{CC}$ and $\mathrm{BdT}$ did not exhibit significant heterozygote deficiency. The mean $F_{\text {is }}$ was 0.10 across all loci for all populations, with four of the five loci exhibiting positive $F_{\text {is }}$ (from 0.048 to 0.315 ), indicating a general excess of homozygotes. The exception to this occurred at locus SA02 where $F_{\text {is }}$ was -0.011 , suggesting an excess of heterozygotes. $F_{\text {is }}$ was significant only at locus SA06 $\left(\chi^{2}=673.75, \mathrm{DF}=132, P<0.0001\right)$. On a perpopulation basis, $F_{\text {is }}$ ranged from 0.001 at ESME to 0.195 at SR (Table 2). The MON population displayed the lowest level of genetic variation $\left(\mathrm{A}=28, H_{\mathrm{e}}=0.368\right.$, Table 2$)$.

The frequency of the most common allele in the isolated MON population ranged from fixation at locus SA02 to 0.57 at locus SA27 (3 alleles). The other three loci contained two alleles (SA29) and four alleles (SA05 and SA06) with an allele frequency for the most common allele $\geq 0.63$ for these three loci. Among the 14 populations, 16 (24\%) of the 68 alleles detected across all five loci were 'private alleles', e.g. they occur in a single population (Table 2). Private alleles

Table 3 Per locus summary statistics of all sampled individuals (N) indicating the observed number of alleles detected at each locus (A),

$\left(\mathrm{A}_{\mathrm{e}} / \mathrm{A}\right)$, average observed heterozygosity $\left(\mathrm{H}_{\mathrm{o}}\right)$ (range), and average expected heterozygosity $\left(\mathrm{H}_{\mathrm{e}}\right)$ (range)

the effective number of alleles $\left(\mathrm{A}_{\mathrm{e}}\right)$, the ratio of effective alleles:alleles

\begin{tabular}{|c|c|c|c|c|c|c|c|c|c|}
\hline Locus & $\mathrm{N}$ & A & $\mathrm{A}_{\mathrm{e}}$ & $\mathrm{A}_{\mathrm{e}} / \mathrm{A}$ & $\mathrm{H}_{\mathrm{o}}$ (range) & $\mathrm{H}_{\mathrm{e}}$ (range) & global $F_{\text {st }}$ & global $R_{\text {st }}$ & HW \\
\hline SA02 & 472 & 11 & 5.29 & 0.48 & $0.640(0.000-0.818)$ & $0.812(0.405-0.819)$ & 0.235 & 0.227 & $* *$ \\
\hline SA05 & 466 & 9 & 3.68 & 0.41 & $0.592(0.392-0.756)$ & $0.728(0.307-0.756)$ & 0.192 & 0.352 & $* *$ \\
\hline SA06 & 476 & 8 & 2.07 & 0.26 & $0.158(0.042-0.558)$ & $0.516(0.056-0.585)$ & 0.450 & 0.220 & $* *$ \\
\hline SA27 & 458 & 29 & 12.82 & 0.44 & $0.718(0.556-0.915)$ & $0.922(0.554-0.914)$ & 0.129 & 0.528 & $* *$ \\
\hline SA29 & 459 & 11 & 3.02 & 0.27 & $0.468(0.098-0.838)$ & $0.669(0.098-0.831)$ & 0.224 & 0.323 & $* *$ \\
\hline Mean across loci & Tot478 & 13.6 & 5.38 & 0.37 & 0.515 & $0.730(0.516-0.922)$ & $\begin{array}{l}0.246 \\
\quad(\mathrm{SE}=0.053)\end{array}$ & $\begin{array}{l}0.330 \\
\quad(\mathrm{SE}=0.168)\end{array}$ & \\
\hline
\end{tabular}

Global $\mathrm{F}_{\mathrm{st}}$ and $\mathrm{R}_{\mathrm{st}}$ values are provided for each locus and deviation from Hardy-Weinberg equilibrium is indicated $* *$ at $P<0.001$ 
Table 4 Mean estimates of genetic differentiation based on microsatellite diversity over five or four loci for different population groupings. All populations, Panama populations (FTS, SR, CJ, BCI, CC, EC, ALP, BDT, MON), Ecuador populations (ESME, MP, TIP,

\begin{tabular}{|c|c|c|c|c|c|c|}
\hline Populations & $\delta$ & $\delta^{\mathrm{a}}$ & $\mathrm{F}_{\text {st }}$ & $\mathrm{F}^{\prime}{ }_{\mathrm{st}}^{\mathrm{a}}$ & $\mathrm{F}_{\mathrm{st}}$ & $\mathrm{F}_{\mathrm{st}}^{\mathrm{a}}$ \\
\hline All populations & 0.418 & 0.164 & 0.586 & 0.105 & 0.234 & 0.018 \\
\hline per $<$ obs & 1.000 & 0.531 & 1.000 & 0.413 & 1.000 & 0.406 \\
\hline Panama & 0.152 & 0.368 & 0.097 & 0.497 & 0.019 & 0.175 \\
\hline per $<$ obs & 0.206 & 1.000 & 0.401 & 1.000 & 0.372 & 1.000 \\
\hline Ecuador & 0.147 & 0.166 & 0.083 & 0.088 & 0.015 & 0.012 \\
\hline per $<$ obs & 0.312 & 0.402 & 0.678 & 0.421 & 0.515 & 0.390 \\
\hline Amazonia & 0.124 & 0.175 & 0.052 & 0.092 & 0.008 & 0.012 \\
\hline per $<$ obs & 0.018 & 0.763 & 0.033 & 0.576 & 0.019 & 0.601 \\
\hline
\end{tabular}

${ }^{\text {a }}$ Indicate data with SA06 removed

were generally more common at the sites with larger sample sizes, though the two populations (BCI and YAS) with the highest number of private alleles did not have the highest effective number of alleles. Four private alleles $(25 \%$ of the total) were present at BCI, Panama (PA) and YAS, Ecuador (EC), two each at BdT (PA), and SR (PA) (13\%) and one private allele occurred at each of the sites $\mathrm{CJ}$ (PA), MP (EC), TIP (EC) and FG (FG) (Table 2).

The values of genetic differentiation estimated by $\delta$ were generally higher than the values of $F^{\prime}{ }_{\text {ST }}$, and both of these tended to be higher than $F_{\text {st }}$ (Table 4). There was a notable difference in results when locus SA06 was excluded from the calculations (Table 4). With all loci analyzed together, a high level of differentiation was found among all 14 populations, with smaller but significant differentiation among the four Amazonia populations. Without locus SA06, significant differentiation was found for all three measures only among the nine populations in Panama, suggesting a large role of this locus in determining the
YAS) Amazonian populations in Ecuador (MP, TIP, YAS). Proportion of cases within the permutation test with values smaller than the observed differentiation (per $<$ obs) genetic structure. The $F_{\text {st }}$ and $R_{\text {st }}$ pairwise tests of genetic differentiation indicated significant differences among all 91 population pairs at the 0.05 level, with the exception of SR and CJ separated by only $26 \mathrm{~km}$ in Panama. $R^{2}$ values were modest $\left(F_{\mathrm{st}}=0.14\right.$ and $R_{\mathrm{st}}=0.14$; Fig. 2$)$. Global $F_{\mathrm{st}}$ and $R_{\mathrm{st}}$ values were 0.246 and 0.330 , respectively, across all 14 populations (Table 3). Within Panama, pairwise $F_{\text {st }}$ estimates were similar between eight of the nine populations, ranging from 0.023 to 0.147 (mean $=0.085$ ) and suggest relatively low, though significant, genetic differentiation among populations. Pairwise $F_{\text {st }}$ values between MON and the other Panama populations were relatively large (range 0.334 to 0.446 ; Fig. 3), indicating that this site is genetically distinct from the other eight Panama sites. Including MON with the other Panama populations nearly doubled the mean $F_{\text {st }}$ among Panama sites to 0.151 .

When alleles were pooled within regions, Panama and Amazonia share two-thirds of their alleles, although the distribution of alleles appears to be more even in Amazonia
Fig. 2 Relationship between geographic and genetic distance measured by $\mathrm{F}_{\mathrm{st}} /\left(1-\mathrm{F}_{\mathrm{st}}\right)$ and $\mathrm{R}_{\mathrm{st}} /$ $\left(1-\mathrm{R}_{\mathrm{st}}\right)$ among 14 populations of Simarouba amara

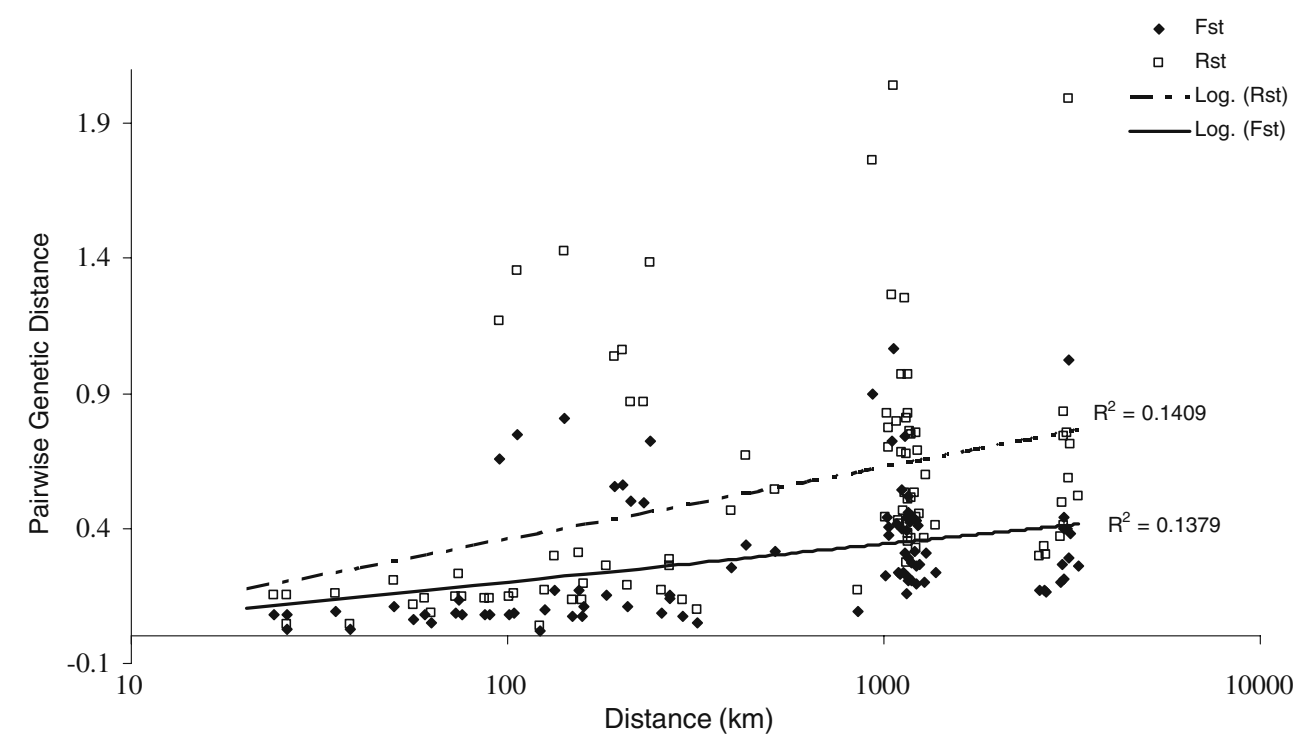




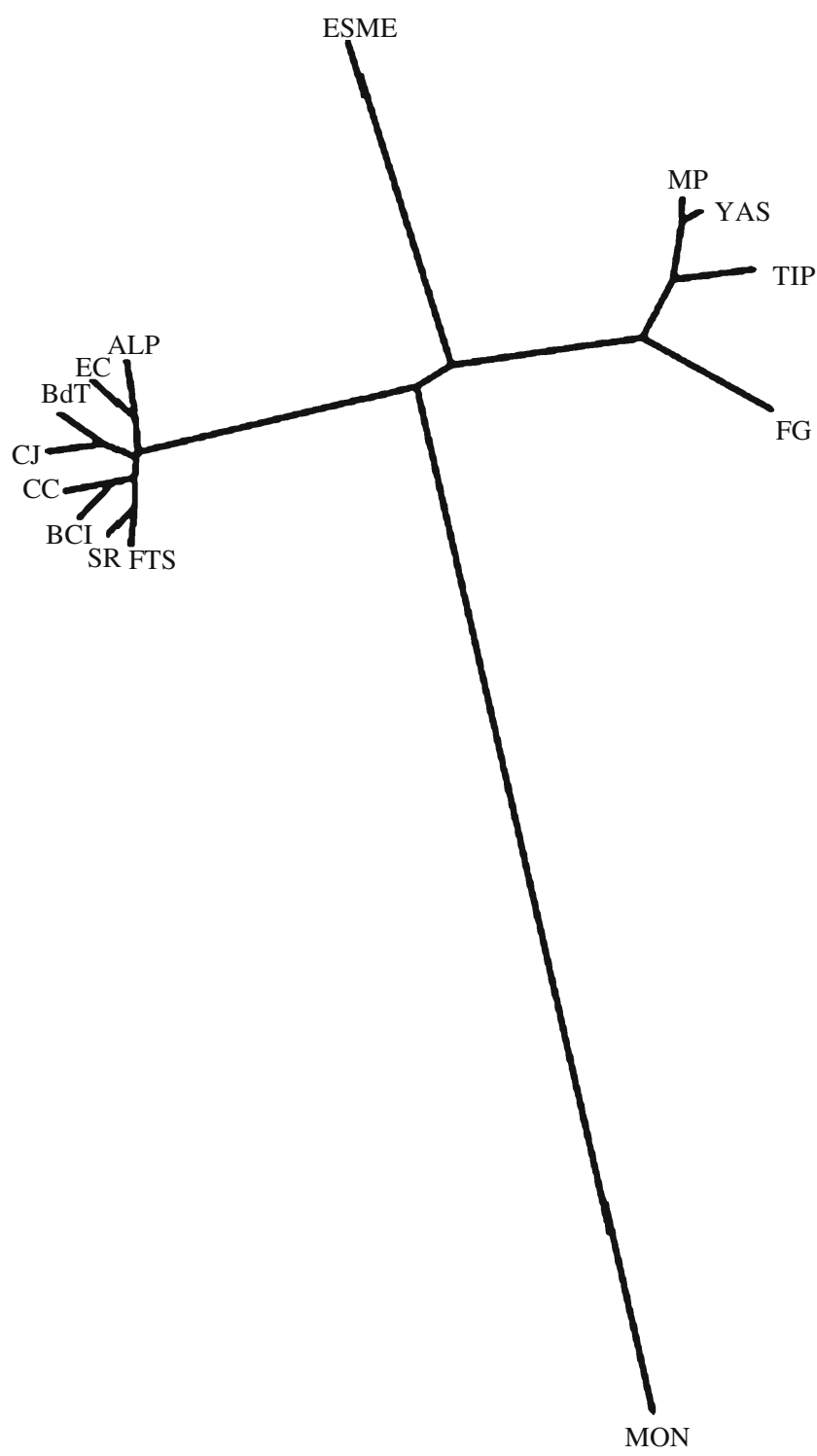

Fig. 3 UPGMA consensus trees for Simarouba amara populations across Central and South America using Nei's D. Branch lengths are proportional for genetic distance

(Table 2). $F_{\text {st }}$ values between Panama and coastal Ecuador (ESME), Amazonia (TIP, YAS and MP) and FG sites were 0.22 in all cases (Table 5) suggesting that an upper limit in $F_{\text {st }}$ values had been reached. Between ESME and the Amazon sites in Ecuador, the $F_{\text {st }}$ value was also 0.22 , and Amazonia exhibited less differentiation than FG $\left(F_{\mathrm{st}}=0.13\right)$. The mean $F_{\text {st }}$ among the three Amazonian Ecuador sites was only 0.041 , showing that these nearby populations are quite similar to one another. Genetic diversity among the four geographic regions (Panama, coastal Ecuador, Amazonia and French Guiana) showed that $94 \%$ of the genetic differentiation occured among regions.

UPGMA consensus trees using Nei's D illustrates the high levels of genetic divergence of populations on the eastern and western sides of the Andes in Ecuador, despite their relatively close geographic distance (Fig. 3). Phylogeographic divergence between cis- and trans-Andean populations was also detected in the form of significant $R_{S T}>$ permuted $R_{S T}$, $(P \leq$ 0.05 , Table 6). There was no contribution of mutation among the cis-Andean (French Guiana and eastern Ecuador) population comparisons. Some significant differences were detected within Central America (e.g. involving MON) but these did not show a consistent pattern.

Overall, we detected a significant $(P=0.006$, Spearman Rank test, ISOLDE) correlation between geographic and genetic distance whether using Nei's D $(0.45), \delta \mu^{2}(0.42)$, $\mathrm{F}_{\text {st }}$ (0.59), $\mathrm{F}_{\text {st }}(0.58)$, or $R_{\text {st }}(0.23)$ (Figs. 2, 3, Tables 2, 4). When restricting the IBD analysis to nine populations within Panama, however, no IBD pattern was detected using $F_{\mathrm{ST}}$ or $R_{\mathrm{ST}}(P>0.05)$, suggesting that the overall IBD pattern may be explained by very distant geographic samples spanning the northern Andean cordilleras.

\section{Discussion}

Similar to findings in studies of other Neotropical tree species, we detected high levels of heterozygosity within populations of $S$. amara. This result is consistent with outcrossing tree species with the potential for long-distance pollen flow (Hamrick and Godt 1996). The generally high level of genetic diversity for $S$. amara populations (with the exception of MON) suggests that historically this species has been relatively common throughout its range, and it has experienced sufficient long-distance gene flow and mutation to counteract the effects of genetic drift (Hamrick 1994b). Across the range sampled, however, we find that most of the genetic differentiation is partitioned among regions (94\%). This leads us to surmise that gene exchange between geographically separated areas is limited, and that populations in these geographically isolated regions have experienced independent evolutionary histories.

A high prevalence of private alleles occurred across all populations $(24 \%$ of all alleles occurred within single populations), with 9 private alleles occurring within the Panama sites and six in the three Amazonian Ecuador sites.

Table 5 Regional Pairwise $\mathrm{F}_{\text {st }}$ values based on Weir and Cockerham (1984)

\begin{tabular}{lllll}
\hline Site & Panama & $\begin{array}{l}\text { Coastal } \\
\text { Ecuador }\end{array}$ & Amazonia & $\begin{array}{l}\text { French } \\
\text { Guiana }\end{array}$ \\
\hline Panama & - & & & \\
Coastal Ecuador & 0.216 & - & & \\
Amazonia & 0.215 & 0.222 & - & - \\
French Guiana & 0.215 & 0.227 & 0.131 & - \\
\hline
\end{tabular}




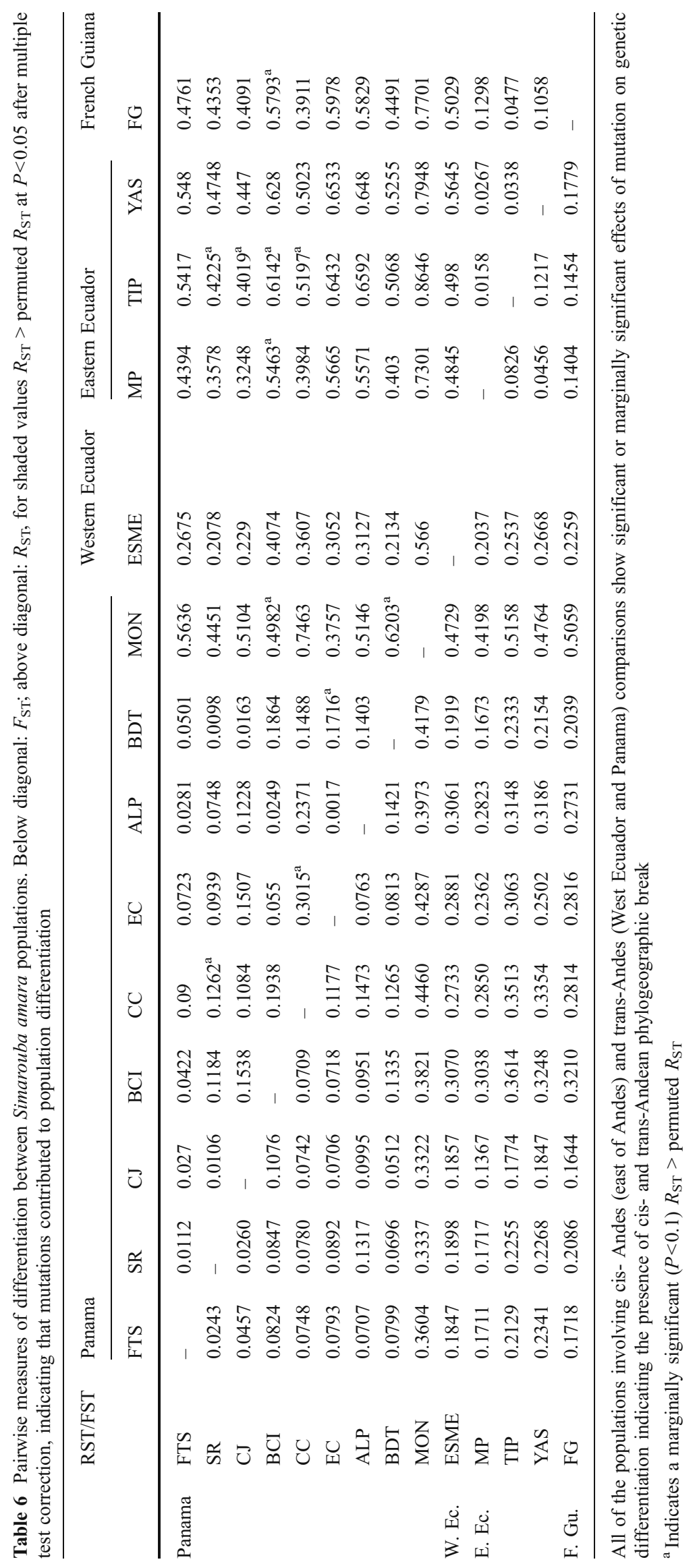


Populations with the highest number of private alleles occurred in BCI and YAS, where there were higher numbers of individuals in the population. Within Panama, private alleles were detected in four of the nine populations; BCI, SR, CJ, and the most northwestern site BdT. Within Ecuador, all three Amazonia sites contained private alleles, in spite of their close proximity and the lack of physical barriers between them. Additional sampling within the smaller sample populations may have changed the number of private alleles detected. Given the high mutation rate of microsatellite markers (Balloux and Lugon-Moulin 2002), our relatively high sample sizes and the broad geographic expanse encompassed by this study, it may not be surprising that we detected such a large number of alleles within individual populations.

We generally predict more similarity among spatially proximate populations due to dispersal limitation and because geographic boundaries may restrict gene exchange between sites. For Cordia alliodora populations sampled across $1,000 \mathrm{~km}$ in Central America, Chase et al. (1995) found significant regional differences between Atlantic and Pacific populations; and topography was shown to play an important role in the local population structure observed for Swietenia macrophylla in Mesoamerica (Novick et al. 2003). Several of the Panamanian populations, including EC, CC, CJ, SR, and MON occur along ridges at higher elevations than the surrounding area. In spite of the short distances between many of the Panama sites, significant pairwise genetic differences are apparent among all but the SR and CJ population pairs that are separated by only $26 \mathrm{~km}$. Long distance gene flow and a shared history may account for the similarity between these two nearby sites. The landscape across Panama is heterogeneous, and topographic features likely have played a role in the distribution of genetic diversity.

Within Ecuador, pairwise $F_{\text {st }}$ and $R_{\text {st }}$ values (Table 6) show that the single coastal population (ESME) is more similar to several Panama populations than it is to the Amazon basin sites even though it is geographically much closer to the Amazon (see also Fig. 3). Biogeographic affinities between the Chocó region of Western Ecuador and Colombia and lower Central America have long been recognized. There are no geographic barriers preventing occasional gene flow between the regions, such as exist between trans-Andean populations. The high level of transAndean differentiation is not surprising, given the time since the formation of the Andean east-west barrier and few contemporary opportunities for gene flow across the northern Andes since its emergence to present elevations in the late Miocene-Pliocene (Gregory-Wodzicki 2000). The existence of an Andean barrier separating sites even within Ecuador was demonstrated by the $R_{\mathrm{ST}}>$ permuted $R_{\mathrm{ST}}$. A similar contribution of mutations to genetic divergence of cross-Andean population was shown for the widespread rain forest tree Symphonia globulifera (Dick and Heuertz 2008), which co-occurs with Simarouba amara across much of its Neotropical range. The crossAndean phylogeographic break has also been shown for big-leaf mahogany, Swietenia macrophylla (Lemes et al. 2010) based on chloroplast SSR data, and probably applies to many other widespread Neotropical tree species.

Over the scale of few to several kilometers, S. amara likely experiences frequent gene movement via both seeds and pollen, at least in an intact forest community. Based on parentage analyses, parent-offspring distances for both paternal and maternal parents of established S. amara seedlings in BCI exceeded $1 \mathrm{~km}$, approximately the maximum distance possible for assessing parentage given the 50 ha forest dynamics plot and surrounding buffer region sampled (Hardesty et al. 2006; Hardesty 2007). Although the forest in Panama and Ecuador is by no means continuous, there remain intermittent forest patches across the increasingly fragmented landscape. In Amazonian Ecuador where the TIP, YAS and MP exist in a continuously forested habitat, significant but slight genetic differentiation $\left(F_{\mathrm{st}}=\right.$ 0.041) occurred among sites. These three western Amazon populations have greater genetic similarity to the geographically distant French Guiana site (PFG) $\left(F_{\text {st }}=0.131\right)$ than to the geographically closer ESME population on the Ecuador coast $\left(F_{\mathrm{st}}=0.220\right)$. In spite of the long distances between the Amazonian Ecuador and French Guiana populations, the lack of significant biogeographic barriers may have allowed gene flow and reduced genetic differentiation.

The pattern of geographic divergence detected in $S$. amara is similar to results for other Neotropical species such as S. macrophylla (Lemes et al. 2003; Novick et al. 2003), Caryocar brasiliense (Collevatti et al. 2001) and Euterpe edulis (Cardoso et al. 2000). For seven Shorea leprosula populations studied in Malaysia using allozymes, however, geographic proximity provided little insight into the relatedness of populations (Lee et al. 2000). Merely estimating isolation by distance and finding a significant result fails to adequately describe the entire picture; the range wide IBD pattern in $S$. amara appears to be caused by geographic barriers such as the northern Andean cordilleras, which involve deep temporal separation of populations leading to the accumulation of mutational differences. These geographic processes are distinct from the drift-dispersal processes that generate isolation by distance patterns (Guillot et al. 2009).

Within Panama, the southernmost population, MON, lies in a dry region on the southern side of the Cordillera del Montuoso in the Azuero Peninsula. It is separated by arid habitats from the forests that connect the other sampled populations in Panama. MON exhibited low allelic diversity, low heterozygosity, and was genetically divergent from other populations based on $\mathrm{F}_{s t}$ analyses. It is worth noting 
that a similar pattern was found in the same general area for S. macrophylla (Novick et al. 2003). In the latter study, Tonosí, from the Azuero Peninsula near the MON population, was the most divergent Mahogany population. The divergence of this population was attributed to a historical population bottleneck. We did not find evidence of historical population bottlenecks in the MON population based on BOTTLENECK analysis, however. Due to the dry climate of the Azuero, the area has probably suffered greater forest contraction during the dry phases of the Pleistocene and it has been geographically isolated from other populations for an extended period. The low diversity and genetic distance may simply be caused by a stronger role of genetic drift in this population, caused by the consistently smaller habitat area and ecological isolation from the Central Cordilleran and Caribbean coastal forests in Panama.

In summary, we found increasing numbers of novel alleles with larger sample sizes of regional populations (Table 2) indicating high levels of genetic diversity and differentiation across the geographic range of Simarouba amara. The high levels of genetic diversity for S. amara are similar to those found for other tropical tree species. However, few studies have sampled over such a broad Neotropical range, and this is only the second study to find evidence of strong phylogeographic structure based on nuclear microsatellite loci. Our data suggest that gene flow has been extensive between populations for $S$. amara at the regional level but has been limited among regions that are separated by geographic barriers. The MON site in the Azuero Peninsula of Panama was a notable outlier and may have experienced an extended period of isolation. The genetic similarity between the French Guiana and Amazonian Ecuador populations provides support for the idea that historical gene flow across a large geographic distance is possible in the absence of geographic barriers. As populations decrease in size and become increasingly fragmented, care must be taken to maintain patches of genetically variable individuals to increase the likelihood of population persistence in the event of environmental change. This may be particularly important in Amazonia and French Guiana where the population density of $S$. amara is much lower than in Panama. If gene flow among populations is sufficient to counteract the effects of drift and maintain diversity, then these regional populations may be able adapt to impending climatic and ecological changes (Hamrick 2004).

\section{Materials and Methods}

\section{Population Sampling}

We analyzed five variable microsatellite loci (Rodriguez von Platen et al. 2000) across 14 natural populations of
S. amara in Central and South America. In Panama, the nine study populations were generally located in unlogged forest sites, with variable altitude and numbers of individuals among sites (Fig. 1, Table 1). In Ecuador, we collected one population from a disturbed coastal area (the only area in which we found $S$. amara), three populations located in undisturbed continuous lowland forest in Amazonia, and in French Guiana we sampled from a single population in the Paracou experimental plot (Fig. 1, Table 1). Sample sizes ranged from 18 to 50 individuals $($ mean $=34.1)$ per site. Each site was GPS referenced and ARCGIS 9.2 was used to calculate the minimum geographic distance between each population pair without exceeding 1,000 $\mathrm{m}$ above sea level (the altitudinal limit of the study species) at $1 \mathrm{~km}$ resolution (i.e. going around rather than over the mountain ranges) (e.g. Sork et al. 1999; Cavers et al. 2005). The geographic distance between populations ranged from $18 \mathrm{~km}$ (Monkey Plot and Yasuni, Ecuador) to 3,562 km (Bocas del Toro, Panama and French Guiana).

We collected leaf tissue from individuals $\geq 10 \mathrm{~cm}$ dbh whenever possible. At sites with low population density, smaller individuals were collected as necessary. Wherever possible, tissue samples were taken from individuals located $>40 \mathrm{~m}$ apart to reduce the likelihood of selecting from related individuals. At the BCI and Yasuni forest plots where larger numbers of individuals occur, we randomly selected from trees with $\geq 10 \mathrm{~cm}$ dbh. Tissue storage and DNA preparation follows protocols described in Hardesty et al. (2005). Briefly, samples were either refrigerated and DNA was extracted within 2 days or they were put into labeled vials and flash-frozen in liquid nitrogen prior to extraction using DNEasy ${ }^{\mathrm{TM}}$ kits (Qiagen Corporation).

\section{Laboratory Methods}

We genotyped all samples at five microsatellite loci containing trinucleotide repeat units using fluorescence-labeled primers: SA02 (TET), SA05 (FAM), SA06 (FAM), SA27 (HEX), and SA29 (FAM) (Rodriguez von Platen et al. 2000). The PCR cocktail $(10.0 \mu \mathrm{l}$ total) contained $250 \mu \mathrm{M}$ of dNTP, $25 \mu \mathrm{M} \mathrm{MgCl}_{2}, 0.0625 \mu \mathrm{l}$ of $10 \mu \mathrm{M}$ Taq polymerase (Qiagen Corporation), and $0.5 \mu$ of the forward and reverse primer (10 $\mu \mathrm{M}$ stock). All PCRs were performed on an MJ Research PTC-200 thermal cycler, using the following protocol: $5 \mathrm{~min}$ at $94^{\circ} \mathrm{C} ; 25$ cycles of $45 \mathrm{~s}$ at $94^{\circ} \mathrm{C}, 1 \mathrm{~min}$ at $53^{\circ} \mathrm{C}$, and $30 \mathrm{~s}$ at $72^{\circ} \mathrm{C}$; ending with $15 \mathrm{~min}$ at $72^{\circ} \mathrm{C}$. Amplification product sizes were inferred with a Rox 400 size standard (Applied Biosystems Incorporated, ABI) on an MJ Research Base Station Automated DNA Analyzer. Forward primers were labeled with fluorescent dyes (HEX, FAM, or TET) on loci with non-overlapping size ranges to allow loading of all five loci in a single lane. 
Microsatellite genotypes were individually scored using Cartographer (MJR). Control individuals were run on different gels to verify consistency between runs. To ensure reliability in scoring gels and avoid genotyping errors (reviewed in Bonin et al. 2004), we genotyped approximately $15 \%$ of all individuals twice. If allele sizes were ambiguous, individuals were analyzed again. Based on the multiple scores, we estimated a $<1 \%$ error rate in allele size assignment.

\section{Genetic Analyses}

The program SPaGeDI 1.2 (Hardy and Vekemans 2002) was used to estimate allele frequencies and mean observed and expected heterozygosity (Nei 1987). $F_{\text {is }}$ was calculated according to Weir and Cockerham (1984). Departure from Hardy-Weinberg equilibrium was tested using Haldane's (1954) exact test, with P-values determined using the Monte Carlo Markov chain method with 1,000 iterations.

We used the four measures $F_{\mathrm{ST}}$ (Wright 1978) and $R_{\mathrm{ST}}$, $F^{\prime}{ }_{\text {ST }}$ (Hedrick 2005) and $\delta$ (Gregorius and Roberts 1986) to analyze the genetic differentiation among populations. For microsatellite markers, $F_{\mathrm{ST}}$ and $R_{\mathrm{ST}}$ values may strongly underestimate differentiation among populations due to high levels of within population heterozygosity. Thus, Hedrick (2005) recently proposed a normalized version of $F_{\mathrm{ST}}\left(F^{\prime}{ }_{\mathrm{ST}}\right)$ that assumes its maximum value of 1 for genetically disjoint polymorphic populations. In contrast to $F_{\mathrm{ST}}$, the measure $\delta$ is based on differences in allele frequencies and thus a purely descriptive, model-independent measure (Gregorius et al. 2007). For all three measures, 1,000 permutations were applied to generate confidence intervals and to check for significance. The unit of permutation was in all cases the multi-locus genotypes of individuals. Genetic differentiation was analyzed twice: once over all loci and once over all loci excluding locus SA06 because that locus likely contains null alleles.

To test for presence of phylogeographic structure, i.e. whether alleles within populations were more related than alleles in the overall sample, $R_{\mathrm{ST}}$ was compared with its value after permuting allele sizes within loci ("permuted $R_{\mathrm{ST}}$ ") using SPAGeDI (10,000 permutations). A significant one-sided test establishes the alternative hypothesis of $R_{\mathrm{ST}}>$ "permuted $R_{\mathrm{ST}}$ " which suggests that allele size mutations contributed to population differentiation and this can be inferred as phylogeographic structure (Hardy et al. 2003). We applied sequential Bonferroni corrections to significance levels of multiple tests (Rice 1989).

Due to distinct low levels of genetic variation detected in one Panama population, we used the program BOTTLENECK (Piry et al. 1999) to determine if any populations show evidence of recent reduction in effective population size. A demographic bottleneck (i.e. severe reduction in effective population size) leads to the preferential loss of rare alleles, whereas new alleles accumulate under population growth. When rare alleles are lost, the frequencies of the remaining alleles are more evenly distributed than under drift-mutation equilibrium, which results in a gene diversity value higher than expected under drift-mutation equilibrium with the same number of alleles. BOTTLENECK permits testing for such "heterozygosity excess", and for "heterozygosity deficit" in the converse case of population expansion, by comparing gene diversity values $H_{\mathrm{E}}$ to their expected values based on the number of alleles, $H_{\mathrm{A}}$, obtained from coalescent simulations.

To visualize potential phylogeographic structure, UPGMA cluster analysis was performed using Phylip 3.573c (Felsenstein 1993) and Nei's standard genetic identity (Nei 1987). Consensus trees were constructed from the best topology based on 1,000 bootstrap replicates. For Nei's genetic identity, differences in sample sizes across populations do not have a discernible effect on sampling variances (Ruzzante 1998).

The ISOLDE feature of GENEPOP was used to test the hypothesis that genetic distance between pairs of populations is dependent upon geographic distance using 1,000 permutations, based upon $F_{\mathrm{st}} /\left(1-F_{\mathrm{st}}\right)$ and $R_{\mathrm{ST}} /\left(1-R_{\mathrm{ST}}\right)$ (Raymond and Rousset 1995; Rousset 1997). In addition to testing for isolation by distance (IBD) across all population pairs, we tested for IBD separately within the nine Panama populations to assess regional differentiation in an area where significant geographic barriers are not present.

Acknowledgments This work was supported by a Mellon Foundation award to support collaboration between Antoine Kremer's INRA lab BD (for Bernd Degen) and STRI (BDH, CWD and EB). The project was supported by additional funds from the National Science Foundation (SPH and DEB 0640379 to CWD), the International Plant Genetics Resource Institute (IPGRI) (CWD and EB), the Center for Tropical Forest Science and the Garden Club of America (BDH). We thank S. Aguilar, P. Ramos, and H. Mogollón for field assistance, and M. Gonzales and O. Sanjur for laboratory support. Support staff from Estacion Biologica Universidad de San Francisco Quito and Estacion Biologica de Yasuní of the Pontifica Universidad Católica del Ecuador, particularly Hugo Navarette, made field visits to the Amazonian sites possible. Helpful suggestions from S. DeWalt, S. Chang and anonymous referees improved this manuscript.

\section{References}

Aide MT, Rivera E (1999) Geographic patterns of genetic diversity in Poulsenia armata (Moraceae): implications for the theory of Pleistocene refugia and the riparian forest. J Biogeogr 25:695-705

Alvarez-Buylla ER, Chaos A, Pinero D, Garay AA (1996) Demographic genetics of a pioneer tropical tree species: patch dynamics, seed dispersal, and seed banks. Evolution 50:1155-1166

Balloux F, Lugon-Moulin N (2002) The estimation of population differentiation with microsatellite markers. Mol Ecol 11:156-165

Bawa KS (1990) Plant-pollinator interactions in tropical rain forests. Ann Rev Ecolog Syst 20:399-422 
Bonin A, Bellemain E, Bronken P (2004) How to track and assess genotyping errors in population genetic studies. Mol Ecol 13:3261-3273

Cardoso SRS, Eloy NB, Provan J, Cardoso MA, Ferreira PCG (2000) Genetic differentiation of Euterpe edulis Mart. Populations estimated by AFLP analysis. Mol Ecol 9:1753-1760

Cavers S, Navarro C, Lowe AJ (2003) Chloroplast DNA phylogeography reveals colonization history of a Neotropical tree, Cedrela odorata L., in Mesoamerica. Mol Ecol 12:1451-1460

Cavers S, Navarro C, Hopkins P, Ennos RA, Lowe AJ (2005) Regional and population-scale influences on genetic diversity partitioning within Costa Rican populations of the pioneer tree Vochysia ferruginea Mart. Silvae Genet 54:258-264

Chase MR, Boshier DH, Bawa KS (1995) Population genetics of Cordia alliodora (Boraginaceae), a Neotropical tree. 1. Genetic variation in natural populations. Am J Bot 82:468-475

Clark DA, Clark DB (2001) Getting to the canopy: tree height growth in a Neotropical rainforest. Ecology 82:1460-1472

Collevatti RG, Grattapaglia D, Hay JD (2001) Population genetic structure of the endangered tropical tree species Caryocar brasiliense, based on variability at microsatellite loci. Mol Ecol $10: 349-356$

Croat T (1978) Flora of Barro Colorado Island. Stanford University, California

Dick CW, Abdul-Salim K, Bermingham E (2003) Molecular systematic analysis reveals cryptic tertiary diversification of a widespread tropical rain forest tree. Am Nat 162:691-703

Dick CW, Heuertz M (2008) The complex biogeographic history of a widespread tropical tree species. Evolution 62:2760-2774

Dick CW, Hardy OJ, Jones FA, Petit RJ (2008) Spatial scales of pollen and seed-mediated gene flow in tropical rain forest trees. Trop Plant Biol 1:20-33

Felsenstein J (1993) Phylip: phylogenetic inference package, Version 3.57c. University of Washington, Seattle

Gregorius H-R, Roberts JH (1986) Measurement of genetic differentiation among subpopulations. Theor Appl Genet 71:826-834

Gregorius H-R, Degen B, König A (2007) Problems in the analysis of genetic differentiation among populations - a case study in Quercus robur. Silvae Genet 56:190-199

Gregory-Wodzicki KM (2000) Uplift history of the Central and Northern Andes: a review. Geol Soc Amer Bull 112:1091-1105

Guillot G, Leblois R, Coulon A, Frantz AC (2009) Statistical methods in spatial genetics. Mol Ecol 18:4734-4756

Haldane JBS (1954) An exact test for randomness of mating. J Genet $52: 631-635$

Hamrick JL (1994a) Genetic diversity and conservation in tropical forests. In: Drysdale RM, John SET, Yapa AC (eds) Proceedings from the international symposium on genetic conservation and production of tropical forest tree seed. pp 1-9

Hamrick JL (1994b) Distribution of genetic diversity in tropical tree populations: implications for the conservation of genetic resources. In: Lambeth CC, Dvorck W (eds) Resolving tropical forest resource concerns through tree improvement, gene conservation and domestication of new species. Proceedings of the IUFRO conference, Columbia

Hamrick JL (2004) Response of forest trees to global environmental changes. For Ecol Manag 197:323-335

Hamrick JL, Godt MJ (1989) Allozyme diversity in plant species. In: Borwn AHD, Clegg MT, Kahler AL, Weir BS (eds) Plant population genetics, breeding and germplasm resources. Sinauer, Sunderland, pp 43-63

Hamrick JL, Godt MJW (1996) Effects of life history traits on genetic diversity in plant species. Philos Trans R Soc Lond B 351:12911298

Hamrick JL, Loveless MD (1989) The genetic structure of tropical tree populations: associations with reproductive biology. In: Bock
JH, Linart YB (eds) The evolutionary ecology of plants. Westview, Boulder, pp 129-146

Hamrick JL, Murawski DA (1991) Levels of allozyme diversity in populations of uncommon tropical tree species. J Trop Ecol 7:395-399

Hardesty BD (2007) How far do offspring recruit from parent plants? A molecular approach to understanding effective dispersal. pp 277-299. In: Dennis AJ, Schupp RJ Green EW, Westcott DA (eds) Seed dispersal: theory and its application in a changing world. CAB International, Wallingford

Hardesty BD, Dick CW, Kremer A, Hubbell SP, Bermingham E (2005) Spatial genetic structure of Simarouba amara Aubl. (Simaroubaceae), a dioecious, animal-dispersed Neotropical tree, on Barro Colorado Island, Panama. Heredity 95:290-297

Hardesty BD, Hubbell SP, Bermingham E (2006) Genetic evidence of frequent long distance recruitment in a vertebrate dispersed Neotropical tree. Ecol Lett 9:516-525

Hardy OJ, Vekemans X (2002) SPAGeDi: a versatile computer program to analyze spatial genetic structure at the individual or population levels. Mol Ecol Notes 2:618-620

Hardy OJ, Charbonnel N, Fréville H, Hueuertz M (2003) Microsatellite allele sizes: a simple test to assess their significance on genetic differentiation. Genetics 163:1467-1482

Hedrick PW (2005) A standardized genetic differentiation measure. Evolution 59:1633-1638

Hubbell SP, Foster RB (1983) Diversity of canopy trees in a Neotropical forest and implications for conservation. In: Sutten SL, Whitmore TC, Chadwick AC (eds) Tropical rain forest: ecology and management. Blackwell Scientific Publications, Oxford

Lee SL, Wickneswari R, Mahani MC, Zakri AH (2000) Genetic diversity of a tropical tree species, Shorea leprosula Miq. (Dipterocarpaceae), in Malaysia: implications for conservation of genetic resources and tree improvement. Biotropica 32:213-224

Lemes MR, Gribel R, Proctor J, Grattapaglia D (2003) Population genetic structure of mahogany (Swietenia macrophylla King, Meliaceae) across the Brazilian Amazon, based on variation at microsatellite loci: implications for conservation. Mol Ecol 12:2875-2883

Lemes MR, Dick CW, Navarro C, Lowe AJ, Cavers S, Gribel R (2010) Chloroplast DNA microsatellites reveal contrasting phylogeographic structure in mahogany (Swietenia macrophylla King, Meliaceae) from Amazonia and Central America. Tropical Plant Biol 3(1):40-49

Losos EC, Leigh EG (eds) (2004) Forest diversity and dynamism: findings from a network of large-scale tropical forest plots. University of Chicago Press, Chicago

Loveless MD (1992) Isozyme variation in tropical trees: patterns of genetic organization. In: Adams WT, Strauss SH, Copes DL, Griffin AR (eds) Population genetics of forest trees. Kluwer, Dordrecht, pp 67-94

Nason JD, Hamrick JH (1997) Reproductive and genetic consequences of forest fragmentation: two case studies of Neotropical canopy trees. J Heredity 88:264-276

Nei M (1987) Molecular evolutionary genetics. Columbia University Press, New York

Novick RR, Dick CW, Lemes MR (2003) Genetic structure of Mesoamerican populations of big-leaf mahogany (Swietenia macrophylla) inferred from microsatellite analysis. Mol Ecol 12:2885-2893

Piry SG, Luikart G, Cornuet JM (1999) BOTTLENECK: a computer program for detecting reductions in the effective population size using allele frequency data. J Heredity 86:502-503

Raymond M, Rousset F (1995) GENEPOP (Version 3.3): population genetics software for exact tests and ecumenicism. J Heredity $86: 248-249$ 
Rice WR (1989) Analyzing tables of statistical tests. Evolution 43:223-225

Rodriguez von Platen H (2000) Genetic diversity of the tropical tree Simarouba amara in fragmented forests in Costa Rica as measured by DNA microsatellites. Dissertation to Yale University School of Forestry and Environmental Studies

Rodriguez von Platen H, Geistlinger J, Berlyn G, Kahl G, Weising K (2000) Characterization of novel microsatellite loci isolated from the tropical dioecious tree Simarouba amara. Mol Ecol Primer Notes 9:498-500

Rousset F (1997) Equilibrium values of measures of population subdivision for stepwise mutation process. Genetics 142:1357-1362
Ruzzante DE (1998) A comparison of several measures of genetic distance and population structure with microsatellite data: bias and sampling variance. Can J Fish Aquat Sci 55:1-14

Sork VL, Nason JD, Campbell DR, Fernandez JF (1999) Landscape approaches to historical and contemporary gene flow in plants. Trends Ecol Evol 14:219-224

Weir BS, Cockerham CC (1984) Estimating F-statistics for the analysis of population structure. Evolution 38:1358-1370

Wright S (1943) Isolation by distance. Genetics 28:114-138

Wright S (1978) Evolution and the genetics of populations, Vol. 4: variability within and among natural populations. The University of Chicago Press, Chicago 